\title{
SEBASTIÁN CELESTINO, CAROLINA LÓPEZ-RUIZ TARTESSOS AND THE PHOENICIANS IN IBERIA, OXFORD UNIVERSITY PRESS, 2016
}

Sebastián Celestino, dyrektor Instytutu Archeologii w Meridzie i Carolina López-Ruiz, profesor studiów klasycznych na Uniwersytecie Stanowym Ohio, po wydaniu książki Tartessos and the Phoenicians in Iberia dołączają do wąskiego grona autorów upowszechniających wiedzę o starożytnej krainie Tartessos lokowanej w dzisiejszej Andaluzji. Publikacje z tego zakresu ukazują się zazwyczaj w języku hiszpańskim. Tym razem mamy do czynienia $\mathrm{z}$ monografią wydaną w języku angielskim przez prestiżowe Oxford University Press. Jest to odpowiedź na wzrastające zainteresowanie dalekim rubieżami południowo-zachodniej Iberii wśród archeologów i historyków starożytności specjalizujących się w dziejach i kulturze basenu Morza Śródziemnego.

Książka składa się z ośmiu rozdziałów, które odzwierciedlają logiczną konstrukcję pracy. W rozdziale pierwszym (In search of Tartessos) przedstawiono stan badań tego regionu, opisując pionierskie dla hiszpańskiej archeologii prace polowe Edwarda Bonsora i poszukiwania mitycznego miasta Tartessos przez Adolfa Schultena. Autorzy wskazują także na polityczne implikacje prowadzonych badań; w dwudziestym wieku Tartessos stało się użytecznym mitem służącym Hiszpanom do budowania narodowej tożsamości. Opisują również najważniejsze odkrycia archeologiczne dokonane w drugiej połowie XX wieku oraz wydarzenia naukowe zapewniające postęp w rozwoju archeologii tartezyjskiej.

Rozdział drugi (Tartessos in Greek Geography and Historiography) szczegółowo przedstawia źródła pisane na temat Tartessos, szczególnie dużo uwagi poświęcając Herodotowi. Autorzy nie ignorują jednak antycznych gatunków literackich, takich jak paradoksografia, dramat czy opisy starożytnych szlaków żeglarskich, periploi, w celu przekazania wszelkich możliwych informacji zawartych w źródłach o tytułowym regionie. Niestety czytelnik literatury antycznej nie jest specjalnie rozpieszczany mnogością passusów o Tartessos; cała wiedza o tej krainie opiera się zaledwie na krótkich wzmiankach.

W rozdziale trzecim (Tartessos through Carthaginian and Roman Lenses) zaprezentowano wizję Tartessos oczami historyków rzymskich lub tworzących dla Rzymian. Podkreślono tu znaczenie źródeł greckich, na których często opierali się autorzy czasów rzymskiej ekspansji w basenie Morza Śródziemnego. Najwięcej miejsca poświęcono Polibiuszowi, Liwiuszowi, Strabonowi i Aveniusowi. W rozdziale tym znajdują się także ciekawe rozważania dotyczące etymologii tak znanych i ważnych dla kultury Półwyspu Iberyjskiego toponimów, 
jak Iberia, Hispania czy wreszcie tytułowego Tartessos. Filologiczne przygotowanie prof. C. López-Ruiz znalazło tu pełny wyraz.

Kolejny rozdział (Tartessos and the Mythological Far West) porusza problematykę obecności Tartessos w starożytnej mitologii. Ta część pracy może wzbudzać kontrowersje, bowiem część z przytoczonych mitów nie wspomina bezpośrednio o Tartessos, a jedynie opisuje fantastyczne wydarzenia, które miały mieć miejsce na dalekich rubieżach zachodniego Śródziemnomorza. Co więcej, są to przekazy pochodzące ze źródeł rzymskich, a więc z czasów dużo późniejszych niż okres funkcjonowania tytułowej krainy jako organizmu społeczno-politycznego. Nie mniej kontrowersyjna, ze względu na brak bezdyskusyjnych argumentów, jest propozycja utożsamiania wymienianego w Starym Testamencie toponimu Tarszisz z Tartessos. Wywód, mimo słabości ewidencji źródłowej, jest jednak poprowadzony w bardzo przekonujący sposób.

Rozdział piąty (Early Cross-Cultural Contacts) omawia zagadnienie kontaktów przede wszystkim między Fenicjanami a ludnością autochtoniczną Półwyspu Iberyjskiego, ale Autorzy odnieśli się także do kolonialnej ekspansji Greków, śmiało porównując greckie i fenickie strefy wpływów w basenie Morza Śródziemnego do starożytnej wersji traktatu z Tordesillas. Problem prekolonizacji postrzegają racjonalnie, tzn. jako nieliczne i niepozostawiające wielu archeologicznych śladów wyprawy kupców i eksploratorów ze Wschodu, słusznie odrzucając postulowaną przez niektóre środowiska naukowe i zgodną z tradycją antyczną datę założenia Kadyksu około roku 1100 p.n.e. Tak wczesna fundacja tego niezwykłego miasta, „drugiego Tyru", nie ma potwierdzenia w źródłach archeologicznych. Jednocześnie opowiadają się za bardzo wczesną, bo mającą miejsce w końcu X w. p.n.e., datą przybycia Fenicjan do miasta Huelva. Obecność ta miała pomóc w planowaniu przyszłego procesu kolonizacji przez Fenicjan. W dalszej części rozdziału S. Celestino i C. López-Ruiz zwracają uwagę na lokalny rdzeń Tartessos, którego materialnym odzwierciedleniem są tzw. stele z południowego zachodu datowane na okres epoki brązu.

Poruszone w rozdziale szóstym (Human and Economic Landscapes) zagadnienia krajobrazów kulturowych oraz podstaw gospodarczych Tartessos są jedną z najciekawszych części tej pracy. Autorzy odważnie zarysowali granice Tartessos, sytuując jego centrum między Kadyksem, Huelvą i Setefillą. Taka definicja najważniejszej części regionu znajduje pełne potwierdzenie w materiale źródłowym. Dwie zamieszczone obok siebie mapy, jedna obrazująca siatkę kolonii fenickich, a druga terytorium Tartessos, wskazują na istotne zależności w kształtowania się tego organizmu. Silna gospodarka Tartessos miała być efektem wspólnej uprawy ziemi przez Fenicjan i ludność lokalną. Widać tu wyraźne nawiązania to forsowanej od dwudziestu lat przez J. Alvara i C. Wagnera, profesorów Uniwersytetu Complutense, zainspirowanej neomarksizmem hipotezy o rolniczej kolonizacji tej części Półwyspu Iberyjskiego. Ewidencja źródłowa nie pozwala jednak na tak daleko idące wnioski. Tzw. importy fenickie odkrywane na autochtonicznych cmentarzyskach andaluzyjskiego interioru są w większości lokalnymi imitacjami produktów fenickich. Co więcej, w hipotezie rozbrzmiewają echa dawno zdezaktualizowanego podejścia kulturowo-historycznego, wedle którego artefakt stanowi materialną emanację społecznego podmiotu, jakim jest etnos. Takie podejście dziwi tym bardziej, że w dalszej części książki Autorzy wielokrotnie dowodzą znajomości aktualnych prądów metodologicznych. Bardzo ciekawym uzasadnieniem przyczyn kryzysu wieku VI p.n.e. prowadzącego do upadku Tartessos jest przekonanie o nagłym trzęsieniu 
ziemi, które miało wywołać falę tsunami pustoszącą wybrzeża atlantyckie oraz estuarium rzeki Gwadalkiwir. To ujęcie zostało oparte na najnowszych ustaleniach hiszpańskich geomorfologów.

Sfera sakralna Tartessos jest tematem siódmego rozdziału (Religious Spaces and Ritual Life). Omówiono w nim podstawy fenickiej religii i jej wpływ na społeczności tartezyjskie. Dużo miejsca poświęcono również jednym z najsłynniejszych stanowisk archeologicznych Półwyspu Iberyjskiego - El Carambolo i Cancho Roano, czyli tartezyjskim sanktuariom, których pierwowzory należy szukać na Bliskim Wschodzie. Autorzy nie wykluczają, że kolonizacja zachodnich rubieży basenu Morza Śródziemnego nie była udziałem tylko ludności fenickiej, lecz również innych grup z terenu wschodniego Śródziemnomorza, na co wskazuje, ich zdaniem, szereg zabytków archeologicznych znajdowanych w Iberii. S. Celestino i C. López-Ruiz sugerują, że wprowadzenie obrządku ciałopalnego Tartezyjczycy zawdzięczali Fenicjanom. Nie można się z tym twierdzeniem zgodzić: wielu badaczy od dawna utrzymuje, że kremacja była stosowana w Andaluzji już w schyłkowym okresie epoki brązu, co potwierdzają także nowo uzyskane daty radiowęglowe ze stanowiska Setefilla. Przy okazji omawiania tej nekropoli, S. Celestino i C. López-Ruiz twierdzą jakoby miały tam zostać znalezione malowane wazy greckie, o czym nie wspomina ani raport wykopaliskowy G. Bonsora i R. Thouvenota $\mathrm{z}$ szeroko zakrojonych prac polowych odbytych $\mathrm{w}$ latach 1926-1927, ani którakolwiek z publikacji M. E Aubet. Warto przypomnieć, że stanowisko to jest badane metodami wykopaliskowymi oraz nieinwazyjnymi przez M. E. Aubet od lat 70. XX wieku. Tym niemniej interpretacja cmentarzysk orientalizujących z terenów zachodniej Andaluzji jest wyważona i wpisuje się w ogólnie przyjęty nurt.

Ostatni rozdział (Art and Technology) dotyczy sztuki i technologii. Rozpoczynają go ciekawe rozważania na temat ceramiki tartezyjskiej, którą należy rozpatrywać w perspektywie szerszych, śródziemnomorskich tendencji w produkcji naczyń. Omówione zostały także podstawy toreutyki, złotnictwa oraz plastyki z kości słoniowej. Zajęto się również problematyką języka tartezyjskiego i lokalnego systemu zapisu; niestety wciąż nieodczytanego.

Krótką, ale ważną częścią pracy jest epilog. Podsumowano w nim dotychczasowe ustalenia i określono miejsce Tartessos w ramach śródziemnomorskiego fenomenu kultury orientalizującej, ale nie zarysowano możliwych kierunków badań tego regionu, zapewne licząc, że stanie się to intelektualnym zadaniem dla czytelników książki. Autorzy postulują jedynie ścisłą współpracę między przedstawicielami różnych dyscyplin, takich jak filologia, archeologia i historiografia, celem lepszego zrozumienia spotkań kulturowych między ludnością „orientalną” a „orientalizującą”.

Książka charakteryzuje się użyciem żywego, potoczystego języka i nie jest pozbawiona humoru; rzadka praktyka w pracach naukowych, do których niewątpliwie należy Tartessos and the Phoenicians in Iberia. Przedstawiane informacje są dobrze udokumentowane, aparat jest obszerny i czytelny. Wielkim walorem jest licząca 37 stron bibliografia. W wykazie starożytnych źródeł pisanych zabrakło jednak pełnych informacji bibliograficznych konsultowanych prac. Użytecznym dodatkiem jest także indeks uwzględniający nazwy geograficzne, postaci oraz podstawowe zagadnienia poruszane w książce. Monografia została wyposażona w 10 map oraz 41 czarno-białych ilustracji. Materiał ikonograficzny wybrano w sposób przemyślany; jest on reprezentatywny dla omawianego obszaru. Tym niemniej po książce sprzedawanej za cenę 80 funtów brytyjskich można oczekiwać również barwnych ilustracji, 
co niestety nie zostało przez wydawcę zrealizowane. Piękne tartezyjskie artefakty publikowane w pracy niewątpliwie na tym bardzo straciły. Wrażenie poprawia estetyczna obwoluta oraz bardzo staranny warsztat edytorski.

Książka autorstwa Sebastiána Celestino i Caroliny López-Ruiz to potrzebna publikacja dla wszystkich zainteresowanych problematyką kontaktów kulturowych w basenie Morza Śródziemnego. Podstawowa jej wartość polega na uszeregowaniu najważniejszych informacji na temat Tartessos i przedstawieniu ich z zwięzłej formie w języku angielskim, a więc zrozumiałym dla szerokiej grupy odbiorców. Rzetelny przegląd obecnego stanu badań i krytyczne podejście do archeologii Tartessos dały, mimo przytoczonych wcześniej zastrzeżeń, znakomite efekty w postaci sprawnie napisanej monografii, która z pewnością przez długie lata będzie pozycją referencyjną dla archeologów i historyków starożytności zajmujących się incydentalnie Półwyspem Iberyjskim. Iberyści powinni jednak sięgać do publikacji źródłowych, a Tartessos and the Phoenicians in Iberia traktować jako książkę pomocniczą.

Michat Krueger

Instytut Archeologii, Uniwersytet im. Adama Mickiewicza w Poznaniu ul. Umultowska 89D, 61-614 Poznań, Poland krueger@amu.edu.pl 